\title{
Water Distribution Forecasting Using Least Square In The Local Government Drinking Water Company Tirta Mon Pase Lhokseumawe
}

\author{
Mutammimul Ula \\ Department of Informatics \\ Universitas Malikussaleh \\ Aceh Utara, Indonesia
}

\author{
Eva Darnila \\ Department of Informatics \\ Universitas Malikussaleh \\ Aceh Utara, Indonesia
}

\author{
Cut Yusra Novita \\ Department of Informatics \\ Universitas Malikussaleh \\ Aceh Utara, Indonesia
}

\begin{abstract}
Local Government Drinking WATER Company TIRTA MON Pase can not fulfill the needs of the people in the Lhokseumawe city because the population of Lhokseumawe city continues to increase every year. Therefore, it has increased the need for the clean water. The artificial intelligence can be used to forecast the continuous distribution of water demand. This study aims to predict the volume of water to $\mathrm{m}$ the water demand using Least Square method. The modeling results using the least squares method, in 2018 , with the population of 218067 people, the water supply needed is 5,689,849,205 liters/day, and the possibility of water leakage is 107573120 liters/day. This system can minimize the possibility of the errors due to the amount of water leakage.
\end{abstract}

Keywords: Forecasting, Least Square, distribution of water

\section{INTRODUCTION}

The population of the Lhokseumawe city has increased every year, therefore, it has an impact on the increased clean water consumption. The population of Lhoksumawein 2009-2013 is 159239-186467, the total quantityof water must be supplied is 867180 liters/year. From 2009-2013, total volume of water supplied is 1739871077 to 3529658057 .Therefore, the data is required for the demand fulfillment of how much the water is needed by people of Lhoksumawe. Therefore data analysis tool is highly needed in the measurement, control processes, formulate information from the data, and help make decisions based on the data ${ }^{1}$.

Local government drinking WATER company (PDAM), which manages the distribution of water in Lhokseumawe city is facing problems regarding the water distribution volume to every district in the region. This is due to the limited volume of water availability and the lack distribution system measurement. The water distribution company must be able to distributesufficient quantity of quality water in for consumers needs ${ }^{2}$

Forecasting tool for determining the quantity of water to distribute is not currently implemented.Therefore, the effectiveness and efficiency of water distribution is very low, moreover, it has been causing water distribution leakage that can affect the availability of the water in Lhokseumawe city. This condition would be harmful to PDAM Tirta Mon PASE because it can not fulfill the consumers needs. The unsatisfied consumerswith the service provided can cause a bad image for the PDAM.

This water distribution problem requires a design with the placement of the shape of the desired input and output. In this section we developed a high performance database application, to produce a report that accurately forecast the amount of water to distribute next year in PDAM Tirta Mon PASE. With the system ability, it is expected that the process of water distribution will be increased and more efficient.
Artificial intelligent can predict the future state through available data in the past and forecast the events in the future on the basis of patterns in the past ${ }^{3}$. The water distribution information system built is software that can help the PDAM in determining the amount of water needed for consumers. The system built is not to substitute for the PDAM in predicting the future distribution of water, but it can help the PDAM to predict the amount of water needed in the future that give some alternatives based on the analysis system result. By combining the expertise of information technology, especially in the field of system forecasting, it is expected to solve the existing problems. Furthermore, decision support systems in water distribution aims to help decision makers utilize particular data and models to solve the various problems which are not structured ${ }^{4}$.

Benefits for forecasting water distribution is to determine the level of accuracy of the least squares method based on the calculation of the mean squared (root mean squared error) ${ }^{5}$. Forecasting data can facilitate the distribution of water and PDAM Tirta Mon PaseLhokseumawe in taking a policy in terms of the future distribution of water. The system is proposed to predict the distribution of clean water to meet the water in the PDAM Lhokseumawe.

Forecasting water distribution is a method to estimate future water needs on the basis of the existing conditions of the water distribution year by year ${ }^{6}$. Forecasting method assumes that the conditions that generate the data in the past arethe same with future conditions, unless the variables are explicitly used in that period ${ }^{5}$.

Least Square method is the most widely used method to determine the equation of the data trend. Least squares method is divided into two cases, namely the even data case and odd data case ${ }^{6}$. Least Square method is most often used to predict $\mathrm{Y}$, because it calculation is more accurate. The least squares line has properties as follows: (1) The sum of the whole points of vertical deviation to lineis zero; (2) The sum of squared vertical deviationsof historical data from the line is the minimum; (3) The line through the mean of $\mathrm{X}$ and $\mathrm{Y}$. 
The least squares method using statistical methods and mathematical calculations to determine the function of straight line to replace the broken line formed by the company historical data. Thus the influences of subjective element canbe avoided.

The concept of this method is expected to solve the problems of drinking water distribution in Lhokseumawe city based on the increasing population trend and the availability of water resources.

\section{STUDY DESIGN}

The method used to predict the distribution of water is using the least squares method. Water distribution planning time predicted for the year 2009-2018.

The least squares method using statistical methods and mathematical calculations to determine the function of straight line to replace the broken line formed by the company historical data. Thus the influences of subjective element can be avoided. Trend equation by the moment method is as follows:

Function equation of this method is:

Y_n $=\mathrm{a}+(\mathrm{b} . \mathrm{X})$

Notes:

Yn: Forecasting for future (Forecasting)

a: constant

$\mathrm{b}$ : slope or inclination coefficient of the trend line

$\mathrm{X}$ : period or the difference in years $(\mathrm{x}=0,1,2,3, \ldots, \mathrm{n})$.

The data used was the number of the population, the number of water compliance, the amount of water needs and the amount of water leakage in the years 2009-2013. The data would be entered into the system for forecasting water distribution. Furthermore, the input data entered was resident, the fulfillment of the water, water demand and water leakage from each data retrieval water drilling in Krueng Pase, in Krueng Peusangan, Drilling Simpang Kramat . The data entered as follows :

\subsection{Population Data}

In view of water distribution need, we needed information about the need of drink waters in the area of planned. Drink water requirement is determined by the condition of the planned area, population growth and socio-economic level that affect water used patterns. As for population data visible on the table below :

Table 1. Lhokseumawe of population in the years 2009 to 2013

\begin{tabular}{|c|c|c|}
\hline NO & TAHUN & Total Of Population \\
\hline 1 & 2009 & 159239 \\
\hline 2 & 2010 & 170504 \\
\hline 3 & 2011 & 171163 \\
\hline 4 & 2012 & 179807 \\
\hline 5 & 2013 & 186467 \\
\hline & Total & 867180 \\
\hline
\end{tabular}

\subsection{The Fulfillment Water}

Fulfillment of clean water was indispensable for the future. Water requirements for the facilities - facilities PDAM should consider the production capacity of existing resources. Analysis of the water can be seen fulfillment needs of the population and area of Lhokseumawe city, The fulfillment of the water as follows :
Table 2. City Water Fulfillment the data Lhokseumawe years 2009 s/d 2013

\begin{tabular}{|c|c|c|c|c|c|}
\hline \multirow{2}{*}{ No } & \multirow{2}{*}{ Years } & \multicolumn{2}{|c|}{ Fulfillment water liter/years } & \multirow{2}{*}{ Total } \\
\cline { 3 - 5 } & & K.pase & K.pesangan & S.bor & \\
\hline 1 & 2009 & 78727 & 489845 & 462762 & 1739872 \\
\hline 2 & 2010 & 10824 & 570493 & 487053 & 2139690 \\
\hline 3 & 2011 & 123308 & 592860 & 507448 & 2333386 \\
\hline 4 & 2012 & 153731 & 792941 & 706867 & 3037122 \\
\hline 5 & 2013 & 165268 & 1078818 & 798160 & 3529659 \\
\hline
\end{tabular}

For the estimate the adequacy requirement clean water, it should be the level of leakage of each distribution area, it is necessary to estimate the stock of water sufficient for the needs of every region in the city of Lhokseumawe. The data leak for each of type in the Lhokseumawe city area are as follows:

Table 3 City Water leak data Lhokseumawe years 2009 s/d 2013

\begin{tabular}{|c|c|c|c|c|c|}
\hline \multirow{2}{*}{$\begin{array}{c}\text { N } \\
0\end{array}$} & \multirow{2}{*}{ Years } & \multicolumn{3}{|c|}{ Water leak liter/years } & \multirow{2}{*}{ Total } \\
\cline { 3 - 5 } & & K.pase & K.peusangan & S.bor & \\
\hline 1 & 2009 & 957450 & 2378590 & 0 & 3336040 \\
\hline 2 & 2010 & 1096759 & 0 & 6468 & 1103227 \\
\hline 3 & 2011 & 0 & 0 & 56790 & 5678936 \\
\hline 4 & 2012 & 2040588 & 0 & 19679 & 2237372 \\
\hline 5 & 2013 & 0 & 56784905 & 0 & 56784905 \\
\hline
\end{tabular}

The scheme of the system is the graphical representation of the system that uses forms of symbols to describe how the data flows through the related process. Schematic diagram of the system consists of a process and describe the scope of the system. Scheme system can describe the entire input to the system or the output of the sistem ${ }^{7}$. The scheme of the whole system can be viewed as follows:

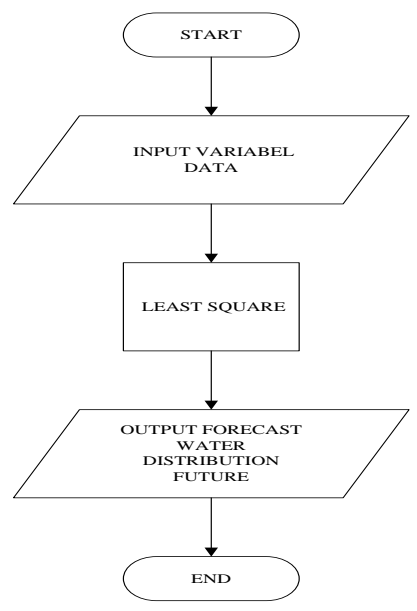

Figure 1 System Schematic 
The explanation of the system scheme is the variable data input will be incorporated into the forecasting process using the least squares method. The result shown is thefuture forecasting of water distribution for the year 2014-2018 and the level of demand fulfillment of the required water.

\section{RESULTS AND DISCUSSION}

The system for forecasting the distribution of clean water using the least squares method in PDAM Tirta Mon PASE is a system that adopting the past years data of a water distribution system for forecasting the future. The data inputted to the system is from 2009, 2010, 2011, 2012, and 2013. This data will generate the forecast the volume of water distribution until the year 2018. The forecasting system involves the head of human resources, chief engineer, and water distribution data. The data processing for water distribution forecasting is assessed from the population data, water demandvolume data, thedemand fulfillment data and the water leakage data every year that calculated using the least squares method.

The water distribution information system built is software that can help the PDAM in determining the amount of water needed for consumers. The system built is not to substitute for the PDAM in predicting the future distribution of water, but it can help the PDAM to predict the amount of water needed in the future that give some alternatives based on the analysis system result.

\subsection{Process Input Data}

The design of input form offulfillment data, the population data, water leaks data, and the demand of the water can be described as follows:

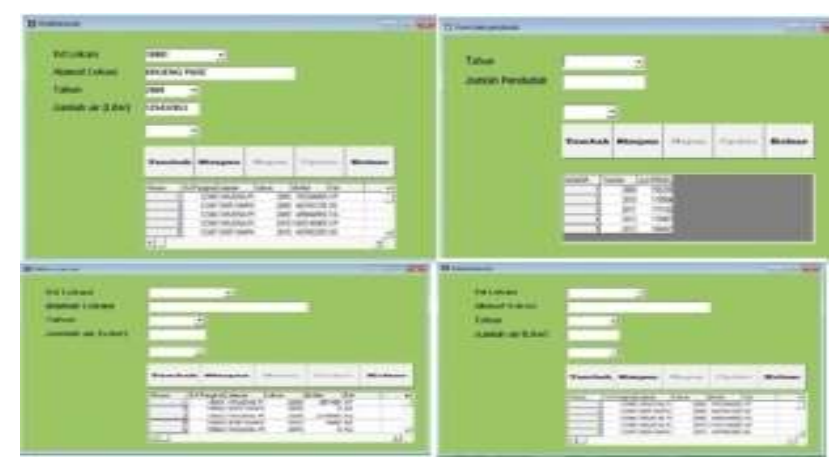

Figure 2 : Form Input Data

The input needs to be entered into the system in water fulfillment form arethe location of the water taken and the volume of water (liters) requiredyear by year. The second form is the population data. The third form is the data of the water leakage that. This data can predict the volume of water leakage in the region. The latest form is the form of water demand as seen from the addresslocation, year and volume needed in a region.

\subsection{Water Distribution Model}

The data input form water requirement is location, adoption year, and the predicted year. The next form of forecasting process is the total of each water sources and the prediction of the level of water demand fulfillment, the population, the water demand and leakage. The form detailshows in Figure 3.

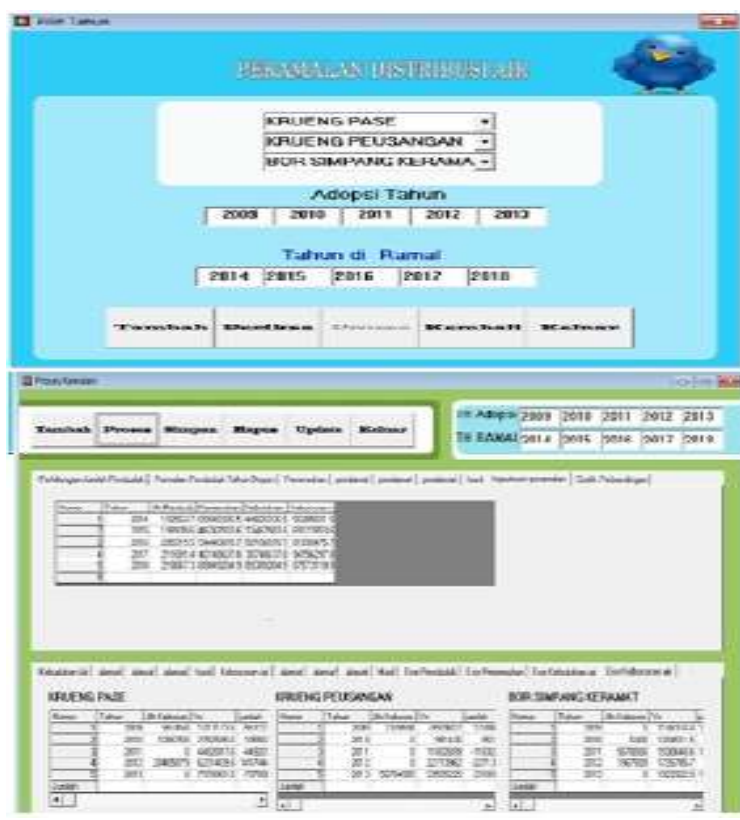

Figure 3.The Forecasting of Water Distribution

The water distribution model using least square is water distribution forecasting based on the adoption of water intakes in 2009-2013 and theforecasting year is 2014-2018. Furthermore, the process of forecasting displayed is based on the input variables and in accordance with the level of data process form.

\subsection{Forecasting Graph Validation}

Forecasting graph validation is used to see the population, theamount of demand fulfillment, the amount of water needed, the amount of water leakage based on the first period and the comparison level of each variable. The detail of the forecasting graph validation is shows in figure 4 .

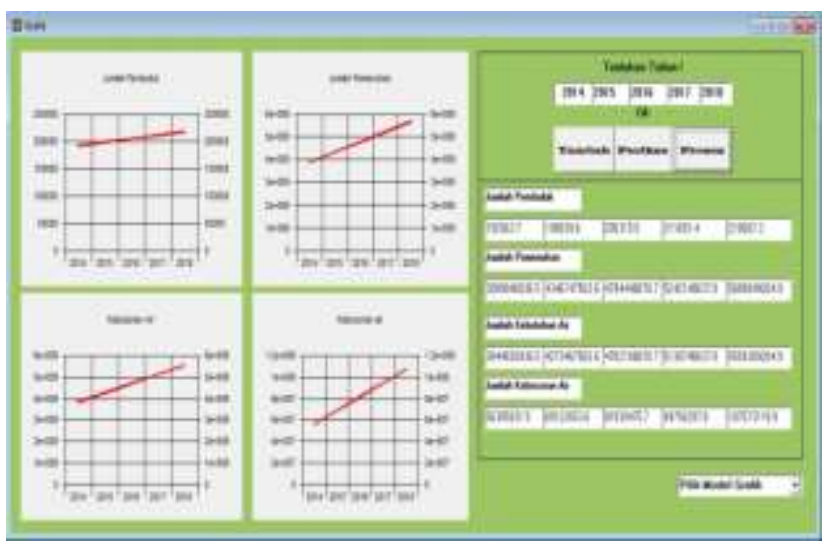

Figure 4. ForecastingGraph Form

Forecasting of the clean water distribution using the least squares method that processes the data is adopting the clean water distribution system with forecasting the future. As an example, the data inputted is from 2009, 2010, 2011, 2012, and 2013. Theforecasting system will predict the amount of water distribution in 2018 based on the data trend. Graph validation form can be displayed via the menu of the report 
form. Graph validation form is used for inputting, correcting, processing the value of the variables. This form consists of a choice of year, the total population, the amount of demand fulfillment, the amount of water needs, and the amount of water leakage. This validation form can show the level of required water demand fulfillment and the level of water leakage.

\section{CONCLUSION}

Based on the result of clean water distribution forecasting using the least squares method,this study concluded that:

1. The least squares method can predict the distribution of drinking water in the town of Lhokseumawe from year 2014-2018. The results of clean water distribution predictionto fulfill the water demand in PDAM Lhokseumawe by using several variables including; the population, the level of water demand fulfillment, the amount of water needs and the amount of water leakage. This system can reduce errors in the distribution of water from each region.

2. The allocation of water in each district is used to calculate the periodic data in 2014-2018. The result calculate the population of Lhoksumawe is 218067,3 in 2018. The amount of water that must be supplyis 5689849204.9 liters/day. The amount of water needed by the people of Lhokseumawe is 5559389204.9 liters/day and the possibility of water leaks in the PDAM system is around 107573119.9 liters/day.

\section{REFERENCES}

[1] Hasan, Iqbal, 2009. The statistical analysis of research data, Bumi Aksara, Yogyakarta.

[2] Hick \& Edward, 1996. Using Pump Technology, Edisi Bahasa Indonesia, Erlangga, Jakarta.

[3] Ginting, Rosnani, 2007. Production system, Graha Ilmu, Yogyakarta.

[4] Turban, E., Aronson, J.E., and Liang, T.P., 2005, Decision Support System and Intelligent System, $7^{\text {th }}$ Edition, Pearson Education Inc., Upper Saddle River, New Jersey.

[5] Makridakis, Wheelwright, \& McGee, 2000. Forecasting Methods and Applications, Edisi Bahasa Indonesia jilid 2, Interaksa, Batam

[6] Prasetya, Hery \& Fitri Lukiastuti, 2009. Operations Management, Media Presindo, Yogyakarta.

[7] Pressman, R.S., 2001, Software Engineering, A Practitioner's Approach, $5^{\text {th }}$ Edition, McGraw-Hill, Inc. New York 